\title{
Modelling Respon Rasio Keuangan terhadap Pembiayaan pada Bank Syariah di Indonesia
}

\author{
Heri Sudarsono \\ Fakultas Ekonomi, Universitas Islam Indonesia \\ Jl. Kaliurang km 14.5, Sleman, Yogyakarta 55584 \\ Email:heri.sudarsono@uii.ac.iad
}

\begin{abstract}
This research is meant to analyze the factors affecting the amount of financing provided by Islamic banking in Indonesia. The data which is used is taken from the financial report of the Shari'a Bank during the 2011-2015 periods by using montly financial statement This study uses a Vector Error Correction Model (VECM) to see the long-term effect and response to shock that occur in the studied variables. The result shows that in the long run, the percentage of third party funds (DPK), capital adequacy ratio (CAR), financial deposit ratio (FDR), percentage profit and loss sharing $(\mathrm{TBH})$, give a positive and significant effect on the financing, while BOPO has negative and significant effect. Return on asset (ROA) and non perfroming finance (NPF) have no significant effect on the financing. In short run, financing and BOPO give a positive and siqnificant effect on teh financing, then DPK, CAR, FDR, TBH have no sinificant effect on the financing. Therfore, shocks that occur in the financing, ROA, CAR, FDR dan NPF positively responded by financing and will be stable in the long term. While the shocks that occur in the percentage of profit and loss sharing, third party funds, and BOPO responded negatively by financing and will be stable in the long term.
\end{abstract}

Keywords: Financing, Third Party Funds, Return on Asset,Capital Adequacy Ratio, Financing Debet Ratio, Percentage of Profit and Loss Sharing, VECM.

\begin{abstract}
Abstrak
Penelitian ini bertujuan untuk menganalisis faktor-faktor yang mempengaruhi pembiayaan perbankan syariah di Indonesia. Data yang digunakan data bulanan dari laporan keuangan bank syariah periode 2010 -2015. Penelitian inimengunakan Vector Error Correction Model (VECM) untuk melihat dampak jangka panjang dan respon terhadap dampak shock pada setiap variabel terhadap pembiayaan. Hasil olah data menunjukkan bahwa DPK, CAR, FDR, TBH berhubungan positif terhadap pembiayaan, sedangkan BOPO berhubungan negatif terhadap pembiayaan. Dalam jangka pendek, pembiayaan dan BOPO berhubugan negatif tetapi DPK, ROA, CAR, FDR, TBH dan NPF tidak berhubungan dengan pembiayaan. Di lain pihah, respon pembiayan terhadap goncangan yang terjadi terjadi pada ROA, CAR FDR dan NPF adalah positif. Sedangkan respon pembiayaan terhadap goncangan yang terjadi pada TBH dan BOPO adalah negatif
\end{abstract}

Kata Kunci: Pembiayaan, Dana Pihak Ketiga, Return on Asset, Capital Adequacy Ratio, Financing Debet Ratio, Percentage of Profit and Loss Sharing, VECM,

\section{PENDAHULUAN}

Pembiayaan merupakan kegiatan menyalurkan dana dari bank syariah sebagai pemilik dana (shohibul maal) kepada pihak yang mengunakan dana (mudharib). Bank syariah menyalurkan pembiayaan dalam bentuk kontrak jual beli, kontrak bagi hasil dan kontrak jasa Pembiayaan dengan kontrak bagi hasil terdiri dari mudharabah dan musyarakah. Pembiayaan mudharabah merupakan pembiayaan yang disalurkan kepada pihak mitra dimana keuntungan dibagi berdasarkan nisbah yang telah disepakati. Sedangkan pembiayaan 
musyarakah, bank syariah dan mitra bersama mengeluarkan dana untuk disalurkan pada mitra atau pengelola dana dengan nisbah yang disepakati sebelumnya. Di lain pihak, pembiayaan jual beli merupakan pembiayaan yang dikeluarkan bank syariah kepada mitra dalam bentuk barang yang dibutuhkan mitra dan mitra membayar pokok pembiayan dan margin setiap bulan sesuai kesepakatan. Pembiayaan jasa yang dalam bentuk ijarah merupakan pembiayaan dengan kontrak sewa dari bank syariah kepada mitra dan mitra dapat mengunakan barang yang menjadi milik bank syariah dengan membayar sewa setiap bulan sesuai dengan kesempatan.

Perkembangan pembiayaan bank syariah dari tahun 2011 sampai tahun 2016 menunjukkan trend yang positif. Trend positif ini dipengaruhi kemampuan manajemen bank syariah dalam mengoptimalkan dana pihak ketiga (DPK) untuk disalurkan dalam bentuk pembiayaan. Disamping itu, ketatnya persaiangan bank syariah menuntut manajemen mencari peluang pembiayaan yang lebih potensial. Gambar 1 menunjukkan pada 2011 total DPK yang berhasil dihimpun sebesar Rp. 102.655 miliar dan terus mengalami peningkatan hingga tahun 2014. Namun, pembiayaan mengalami penurunan pada tahun 2015 dengan nilai sebesar Rp 154.527 miliar atau turun sebesar 28, 99\% dari pembiayaan tahun 2013 dengan nilai Rp 184.122 miliar. Pada tahun 2016 pembiayaan kembali naik sebesar 13, 20\% atau Rp 178.043 miliar. Besarnya pembiayaan syariah ini sangat dipengaruhi oleh besarnya dana bank yang berasal dari DPK. Hal tersebut dapat diketahui dari pertumbuhan pembiayaan seiring dengan perkembangan DPK bank syariah.

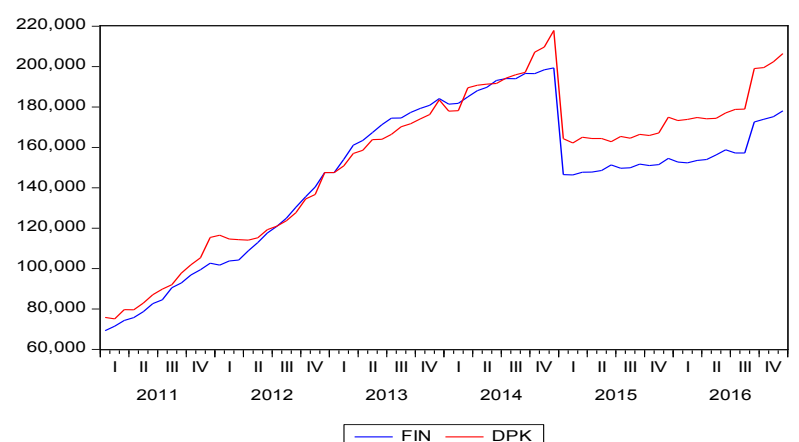

Gambar 1. Perkembangan Pembiayaan dan DPK bank syariah pada 2011-2015
Dana Pihak Ketiga (DPK) merupakan dana yang berasal dari mitra yang berupa tabungan, deposito dan giro didasarkan perjanjian penyimpanan dana dalam berbagai bentuk. Diantara tiga bentuk DPK, pendanaan dalam bentuk deposito memiliki prosentase yang paling besar di banding dengan tabungan dan giro. Besarnya pendanaan dalam bentuk deposito ini dipengaruhi oleh strategi manajemen bank untuk mendapatkan dana yang memiliki dimanfaatkan dalam jangka panjang. Selain itu, mitra cenderung memiliki simpanan dana yang besar beralih ke deposito karena nisabah bagi hasil yang diberikan bank lebih banyak dari tabungan. Perkembangan DPK dari tahun 2011 sampai 2014 secara nominal mengalami kenaikan tetapi prosentase kenaikan DPK dari tahun 2011 sampai 2014 mengalami penurunan. Ditahun 2011 sebesar Rp 115, 415 miliar kemudian turun 21,75\%, $19,62 \%, 15,75 \%$ di tahun 2011, 2012, dan 2013. Penurunan cukup tajam pada tahun 2015 dengan nilai nominal Rp 174, 895 miliar atau turun sebesar 24,56\% dari tahun 2014. Namun pada tahun 2016 DPK kembali naik menjadi 15, 25\% atau sebesar Rp 206,407 miliar. Perkembangan jumlah DPK ini mempengaruhi besaran pembiayaan bank syariah pada periode yang sama.

Pendapatan yang diterima bank melalui pembiayaan digunakan untuk membiayai aktivitas operasional bank. Semakin besar pendapatan bank syariah maka semakin besar tingkat kemampulabaan atau profitabilitas (ROA). Pembiayaan bagi syariah masih menjadi salah satu faktor penentu bagi peningkatan pendapatan selain pendapatan yang diperoleh dari bonus wadiah SBIS, secondary market, atau jasa-jasa perbankan; seperti ATM, bank garansi, letter of credit dan sebagainya. Besarnya pengaruh pembiayaan terhadap ROA dapat diketahui dari perkembangan data ROA mengiringi perkembangan pembiayaan. Pada tahun 2011, tingkat ROA bank syariah sebesar 1, 79\%, kemudian naik pada tahun 2012 sebesar 2.1\%. Namun, pada tahun 2014, tingkat pembiayaan turun diikuti dengan turunnya ROA sebesar 0,8\%. Di akhir pengamatan, pada tahun 2015-2016 menunjukkan perkembangan berbeda dari tahun 2014. Pada tahun 2015, 
ketika ada kenaikan pembiayaan, ROA naik sebesar $2.2 \%$ dan diikuti pada 2016 naik sebesar $2,27 \%$

Modal bank dapat juga digunakan untuk menjaga kemungkinan timbulnya risiko atas pengunaan aset. Untuk menanggulangi kemungkinan risiko yang terjadi, maka suatu bank harus menyediakan modal minimum. Semakin tinggi nilai capital adequacy ratio (CAR) mengindikasikan bahwa bank mempunyai modal yang cukup baik dalam menanggung risiko-risiko pemanfaat kekayaan bank, termasuk di dalamnya resiko pembiayaan. Bank syariah rata-rata tidak memiliki masalah berkaitan dengan besaran CAR karena ketentuan minuman CAR yang harus dipenuhi diatur oleh peraturan BI. CAR bank syariah relatif stabil dari tahun ke tahun bergerak pada kisaran 15\%-17\%. Misalnya, pada tahun 2011, CAR bank syariah sebesar 16,63\%. Kemudian sempat turun pada tahun 2012 dan 2013 sebesar $14,13 \%$ dan $14,42 \%$. Namun kemudian naik kembali pada tahun 2014 sebesar 16.,1\% dan turun kembali $15,02 \%$ dan $15,95 \%$ pada tahun 2015 dan 2016.

Financial deposit ratio (FDR) menggambarkan perbandingan antara besarnya kemampuan bank syariah dalam menyalurkan pembiayaan dengan seluruh dana yang dapat dihimpun dari masyarakat. Nilai FDR dari tahun 2011 sampai tahun 2014 memiliki nilai yang berfluktuatif dan cenderung menurun. Tahun 2013 nilai FDR pada bank syariah mencapai $100.32 \%$, merupakan rasio tertinggi selama lima tahun terakhir. Akhir tahun 2014 nilai FDR pada bank syariah mengalami penurunan sebesar 91,5\% menjadi $8.82 \%$ di tahun 2015. Penurunan nilai FDR menunjukkan fungsi intermediasi yang dilakukan oleh bank syariah mengalami penurunan pada tahun 2014 dan 2015. Penurunan pembiayan dan DPK pada tahun 2014 dan 2015 secara langsung berpengaruh pada besaran FDR. Namun besarnya pembiayaan bank syariah sangat tergantung dari besarnya pendanaan dari desposito mitra dalam periode yang sama.

Tingkat bagi hasil (TBH) bank syariah menentukan besaran pendapatan bank secara tidak langsung tetapi TBH lebih langsung mempengaruhi besaran pendanaan dan pembiayaan. Bila tingkat nisbah bagi hasil pada mitra yang menambung dan deposito meningkat akan mempengaruhi peningkatan nisbah bagi hasil pada pembiayaan bank syariah. Demikian pula sebaliknya bila TBH di DPK menurun, nisbah TBH pada pembiayaan akan menurun. Semakin tinggi nisbah bagi hasil untuk bank syariah dibanding mitra pada produk pembiayaan maka bank syariah memiliki potensi mendapat penghasilan atau ROA yang lebih tinggi. Pada tahun 2012, TBH sebesar 6,49\% kemudian naik pada tahun 2013 sebesar 7,08\% dan pada tahun 2014 TBH naik sampai 14,02\%. Kemudian pada tahun 2015 dan 2016 turun pada tingkat 13,94\% dan 12,92\%. Kenaikan TBH pada tahun 2014 dan 2015 direspon negatif oleh mitra dengan ditandai turunnya nilai DPK dan pembiayaan pada periode yang sama.

Non performing financing (NPF) adalah rasio tingkat pengembalian pembiayaan atas total pembiayaan yang disalurkan bank syariah. Semakin rendah rasio NPF, semakin rendah tingkat pembiayaan bermasalah yang terjadi. Tingkat kolektabilitas pembiayaan perbankan syariah tidak semua lancar karena beberapa pembiayaan menghadapi risiko pasar yang tidak mudah dikendalikan oleh bank. Perkembangan NPF dari tahun 2011 sampai 2016 mengalami kondisi yang fluktuatif. Pada tahun 2011 tingkat NPF sebesar 2,52\%, kemudian pada tahun 2012 mengalami penuruan sebesar 2,22\% kemudian naik lagi pada tahun 2013 dan 2014 sebesar $2,62 \%$ dan 4.33 . NPF naik tajam pada tahun 2015 dan 2016 dengan nilai sebesar $8,2 \%$ dan $11.14 \%$. Kenaikan NPF pada periode 2013-2014, berhubungan dengan besaran pembiayaan yang ditawarkan bank syariah sebelum tahun 2013 dan kemudian pembiayan turun tajam pada tahun 2014. Turunnya NPF pada tahun 2014 bukan semata-mata pembiayaan bermasalah meningkat, tetapi karena menurunnya pembiayaan bank syariah. Turunnya pembiayaan menyebabkan rasio pembiayaan bermasalah dan total pembiayaan atau NPF bank syariah meningkat pada tahun 2015.

Tingkat efisiensi kinerja operasional ini sering diukur menggunakan beban operasional terhadap pendapatan operasional atau biasa disingkat dengan BOPO. Semakin kecil rasio BOPO menunjukkan semakin efisien 
bank syariah dalam mengeluarkan biaya untuk memaksimalkan pendapatan. Bank dalam kondisi bermasalah bila bank tersebut tidak beroperasi dengan efisien yang dapat ditunjukan dari dari rasio $\mathrm{BOPO}$ yang tinggi. Tingkat BOPO dari tahun 2010 sampai 2016 relatif fluktuatif pada kisaran $70 \%-80 \%$. Tingkat BOPO pada tahun 2010 sebesar 78,41\%, kemudian menurun pada tahun 2012 dan 2013 sebesar 74, 75\% dan 78,59\%. Tahun 2014 meningkat 79,3\%, kemudian naik tajam pada tahun 2015 dan 2016 sebesar 88,09\% dan $87,09 \%$. Kenaikan BOPO pada tahun 2015 dan 2016 berhubungan dengan turunnya tingkat pembiayaan pada tahun yang sama. Turunya pembiayaan mempengaruhi turunnya pendapatan operasional bank. Pada saat yang sama beban operasional relatif tetap dibanding dengan tingkat pendapatan operasional yang menurun sehingga menyebab BOPO pada tahun 2015 dan 2016 meningkat.

Berdasarkan penjelasan di atas, maka permasalahan yang dapat dirumuskan dalam penelitian ini adalah apakah rasio keuangan berpengaruh terhadap tingkat pembiayaan bank syariah di Indonesia. Untuk mengetahui hal tersebut maka penelitian ini akan mengkaitkan sejauh mana pengaruh rasio keuangan mempengaruhi pembiayaan bank syariah. Variabel yang digunakan dalam penelitian ini, yaitu Pembiayaan (FIN), Dana Pihak Ketiga (DPK), Return on Aset (ROA), Capital Adequacy Rasio (CAR), Financial to Deposit Rasio (FDR), Tingkat Bagi Hasil (THB), Non Performing Finance (NPF) dan Rasio Beban Operasional dengan Pendapatan Operasional (BOPO)

\section{Telaah Pustaka dan Pengembangan Hipotesis}

Penelitian tentang pembiayaan bank syariah telah dilakukan oleh beberapa peneliti pada periode berbeda dengan pengunaan variabel yang beragam. Pembiayaan bank syariah mendapatkan perhatian peneliti dikarenakan digunakan untuk mengukur kemampuan manajemen bank syariah dalam memanfaatkan instrumen keuangan yang dimiliki dalam mengoptimalkan dana yang disalurkan. Pembiayaan perbankan syariah menurut Peraturan Bank Indonesia No.5/7/ PBI/2003 adalah penanaman dana bank syariah baik dalam rupiah maupun valuta asing dalam bentuk pembiayaan, piutang, gardh, surat berharga syariah, penempatan, penyertaan modal, penyertaan modal sementara, komitmen dan kontinjensi pada rekening administratif serta sertifikat wadi' ah Bank Indonesia.

Dana pihak ketiga (DPK) adalah penghimpunan dana bank yang diperoleh dari mitra masyarakat berupa tabungan, deposit dan giro. DPK merupakan kontrak kerjasama usaha antara mitra yang pemilik dana kepada bank syariah sebagai pengelola dana. Dari pengelolaan dana dari mitra, bank syariah akan mendapat keuntungan dibagi sesuai nisbah yang disepakati sebelumnya. Semakin besar DPK yang diperoleh bank syariah maka semakin besar dana pembiayaan bank yang disalurkan. Dari penelitian Meydianawati (2007), Qolby (2013), Dyatama (2015), Priyanto (2016), Jamilah (2016) dan Destiana (2016) membuktikan bahwa besarnya DPK mempengaruhi besarnya pembiayaan yang disalurkan oleh bank syariah.

Return on asset (ROA) untuk mengukur kemampuan manajemen bank dalam memperoleh keuntungan dari aset yang dimiliki. Semakin besar tingkat keuntungan (ROA) menunjukkan semakin besar kemampuan manajemen bank mampu menghasilkan dana yang berbentuk investasi. Semakin besar investasi maka semakin besar kemampuan bank syariah menyalurkan dana dalam bentuk pembiayaan. Namun, dari penelitian sebelumnya pengaruh ROA terhadap pembiayaan menunjukkan hubungan yang beragam. Dalam penelitian Meydianawati (2007), Giannini (2013) dan Qolby (2013) menemukan bahwa ROA berpengaruh positif terhadap pembiayaan. Sedangkan hasil penelitian Dyatama (2015) dan Jamilah, (2016) menemukan bahwa ROA berpengaruh negatif terhadap pembiayaan. Berbeda dengan hasil penelitian sebelumnya, Nasution (2016), Adzimatinur et al, (2016) dan Destiana (2016) menemukan bahwa ROA tidak berpengaruh terhadap pembiayaan.

Capital adequacy ratio (CAR), rasio yang untuk mengetahui kemampuan manajemen dalam menutup resiko atas pengunaan aset bank syariah. CAR yang tinggi menunjukan kemampuan keuangan bank syariah yang dapat 
digunakan untuk keperluan pengembangan usaha dan menghindari potensi kerugian yang diakibatkan oleh penyaluran pembiayaan. Hal ini menunjukkan bahwa semakin tinggi CAR maka pihak manajemen bank semakin memiliki jaminan atas kerugian, bila mengunakan dana untuk disalurkan dalam bentuk pembiayaan. Hubungan positif antara CAR dan pembiayaan telah diteliti oleh Giannini, (2013), Priyanto (2016) dan Jamilah, (2016). Namun penelitian menunjukkan bahwa CAR tidak berpengaruh terhadap pembiayaan, seperti dalam penelitian Dyatama (2015) dan Destiana (2016).

Financing to deposit ratio (FDR) merupakan rasio dana yang disalurkan dalam bentuk pembiayaan dengan dana diperoleh atau DPK. Semakin tinggi FDR menunjukkan semakin besar pula dana yang disalurkan dalam bentuk pembiayaan dan demikian pula sebaliknya. Di sisi lain FDR yang terlampau rendah akan dapat menimbulkan risiko likuiditas atau over likuid karena hal tersebut bertanda bank mengalami kesulitasn menyalurkan pembiayaan. Keadaan ini menjadikan beban bank semakin tinggi karena kemampun bank dalam menghasilkan pendapatan dari penyaluran pembiayaan menurun. Dalam penelitian sebelumnya tingkat FDR menunjukkan dampak beragam terhadap pembiayaan. Dalam penelitian Meydianawathi (2007), Kusumati (2013), Nasution (2016) dan Adzimatinur et al, (2016) menemukan bahwa FDR berhubungan positif terhadap kenaikan pembiayaaan. Sementara itu, Giannini (2013) menemukan bahwa FDR berhubungan negatif terhadap pembiayaan Dan penelitian Wahab, (2014) ditemukan bahwa FDR tidak berhubungan dengan besarnya pembiayaan

Tingkat bagi hasil (TBH) merupakan proporsi pembagian hasil usaha yang disepakati kedua belah pihak antara bank syariah dengan mitra pengelola dana. Bank syariah pada umumnya menentukan bagi hasil didasarkan atas beban operasional bank, tingkat bunga bank konvensional dan trend inflasi. Jenis pembiayaan yang berhubungan dengan TBH adalah pembiayaan mudharabah dan musyarakah yang mengunakan skim bagi hasil. Pembiayaan akan meningkat apabila nisbah bagi hasil rendah atau lebih rendah daripada tingkat bunga bank konvensional, Hasil temuan tentang hubungan TBH kebanyakan menemukan bahwa pengaruh TBH terhadap pembiayaan tidak siqnifikan. Seperti dalam penelitian Giannini (2013), Wahab (2014) dan Adzirmatinur et al (2015) menemukan tidak adanya hubungan jangka pendek dan panjang antara tingkat bagi hasil dengan pembiayaan

Non performing finance (NPF) dapat merupakan rasio antara pembiayan bermasalah dengan jumlah total pembiayaan di bank syariah. NPF yang tinggi dapat menyebabkan bank mengurangi jumlah dana yang disalurkan ke dalam bentuk pembiayaan karena harus membentuk cadangan penghapusan yang besar. Sebaliknya, semakin rendah NPF maka bank cenderung akan meningkatkan jumlah pembiayaan yang disalurkan kepada mitra. Dampak negatif NPF terhadap pembiayaan di bank syariah telah ditemukan dibeberapa penelitian. Hasil penelitian Adzimatinur et al, (2016) membuktikan bahwa NPF berpengaruh negatif terhadap pembiayaan. Namun hal yang berbeda dinyatakan oleh Giannini (2013), Wahab (2014), Jamilah (2016), Nasution (2016) yang menyatakan bahwa NPF tidak berpengaruh terhadap pembiayaan.

Biaya operasional terhadap pendapatan operasional (BOPO) yaitu rasio yang digunakan untuk mengukur perbandingan biaya operasi terhadap pendapatan operasi yang diperoleh bank. Semakin rendah rasio biaya operasional terhadap pendapatan operasional mengindikasikan semakin efisien biaya operasional yang dikeluarkan oleh bank syariah. Efisiensi biaya operasional menunjukkan kemampuan manajemen bank syariah mengelola pendapatan operasional untuk menutup biaya operasional. Oleh karena, semakin efisien biaya operasional bank syariah akan menjadikan pihak manajemen meningkatkan jumlah pembiayaan. Hasil penelitian Jamilah, (2016) menemukan bahwa BOPO berpengaruh negatif terhadap ROA. Sedangkan dalam penelitian Nasution (2016) dan Adzimatinur et al, (2016) menunjukkan bahwa BOPO tidak berpengaruh terhadap pembiayaan.

\section{METODE PENELITIAN}

Data yang digunakan dalam penelitian ini merupakan data sekunder yang berupa 
data runtut waktu (time series). Data dalam penelitian ini diperoleh dari dari laporan statistik Otoritas Jasa Keuangan (OJK) dari tahun 2011 sampai 2016 serta dokumen lain yang mendukung penelitian ini. Dalam variabel time series perlu diuji terlebih dahulu stasioner data untuk melihat variasi disekitar garis kontsan. Uji stasioner menggunakan uji ADF yang dengan menguji hipotesis $H_{0}: \gamma=$ 0 , terdapat unit root.

Untuk melihat kointegrasi antara dua atau beberapa variabel dilakukan uji kointegrasi penelitian ini mengunakan estimasi maksimum likehood kointegrasi yang diusulkan oleh Johansen untuk menguji apakah ada kointegrasi di antara variabel. Selain itu uji Johansen digunakan untuk untuk menemukan jumlah kointegrasi kelompok vektor. Apabila antar pembiayaan, DPK, ROA, CAR, FDR, $\mathrm{TBH}, \mathrm{NPF}$ dan BOPO berkointegrasi, sifat hubungan jangka pendek di antara variabel dapat dinyatakan dalam bentuk vector error correction model (VECM).

Model VECM memperhitungkan waktu koreksi kesalahan, sehingga dengan model ini dapat ditemukan hubungan jangka dan pendek dari pra dan pasca saling interaksi antar variabel. Dalam jangka panjang, VECM dapat memeriksa hubungan jangka panjang dari kesalahan syarat dan regresi variabel dalam sistem. Sehingga dapat memperoleh efek umpan balik antar variabel pembiayaan, DPK, ROA, CAR, FDR, TBH, NPF dan BOPO dari interaksi timbal balik dalam jangka pendek dan jangka panjang. Adapun model yang digunakan dalam penelitian ini adalah sebagai berikut :

$$
\begin{aligned}
& \Delta F I N_{t}=a_{1}+\beta_{t}\left(e_{t-1)}\right)+\sum_{i=0}^{m} a_{1, i} \Delta F I N_{t-1}+ \\
& \sum_{1=0}^{m} b_{1, i} \Delta D P K_{t-1}+\sum_{1=0}^{m} c_{1, i} \Delta R O A_{t-1}+\sum_{1=0}^{m} d_{1, i} \Delta C A R_{t-1}+ \\
& \sum_{i=0}^{m} e_{1, i} \Delta F D R_{t-1}+\sum_{1=0}^{m} f_{1, i} \Delta T B H_{t-1}+\sum_{1=0}^{m} g_{1, i} \Delta N P F_{t-1}+ \\
& \sum_{1=0}^{m} h_{1, i} \Delta B O P O_{t-1}+\varepsilon_{1 t}
\end{aligned}
$$

dimana FIN adalah pembiayaan; $\beta_{1}$ $\sim \beta_{8}$ adalah tingkat penyesuaian parameter, yaitu faktor penyesuaian koreksi kesalahan jangka panjang; $e_{\mathrm{t}-1}$ adalah syarat kesalahan pra koreksi; DPK adalah dana pihak ketiga; ROA adalah return on asset: CAR adalah capital adequacy rasio; FDR adalah financing to deposit ratio; $\mathrm{TBH}$ adalah tingkat bagi hasil: NPF adalah non performing finance; BOPO adalah rasio beban operasional dengan pendapatan operasional; $a_{i} \sim d_{i}$ adalah faktor penyesuaian dinamis jangka pendek; $m$ adalah periode lag untuk semua variabel; $\varepsilon_{1 t} \sim \varepsilon_{8 t}$ adalah white noise.

Analisis impulse response function (IRF) dan variance decomposition (VD) diperlukan untuk mengetahui shock variabel pembiayaan, DPK, ROA, CAR, FDR, TBH, NPF dan BOPO terhadap pembiayaan. Pada umumnya analisis IRF diperlukan untuk mengetahui pengaruh shock suatu variabel terhadap variabel itu sendiri dan variabel-variabel lainnya di dalam persamaan. IRF menggambarkan dampak dari shock suatu variabel terhadap variabel-variabel yang lain. Dengan IRF dapat diketahui berapa lama pengaruh shock suatu variabel terhadap variabel-variabel yang lain. Selain itu, IRF

Tabel 1. Hasil Uji Akar Unit Level dan First Difference

\begin{tabular}{ccccccc}
\hline \multirow{2}{*}{ Variabel } & \multicolumn{2}{c}{ Level } & \multicolumn{3}{c}{ First Difference } \\
\cline { 2 - 6 } & $\begin{array}{c}\text { Dickey } \\
\text { Fuller Test }\end{array}$ & Probabilitas & Keterangan & $\begin{array}{c}\text { Dickey } \\
\text { Fuller Test }\end{array}$ & Probabilitas & Keterangan \\
\hline LNFIN & -3.008019 & 0.0389 & Tidak Stasioner & -7.346396 & 0.0000 & Stasioner \\
LNDPK & -2.442036 & 0.1342 & Tidak Stasioner & -8.207062 & 0.0000 & Stasioner \\
ROA & -3.477143 & 0.0115 & Stasioner & -11.76207 & 0.0001 & Stasioner \\
CAR & -5.773269 & 0.0000 & Stasioner & -10.52578 & 0.0001 & Stasioner \\
FDR & -1.656910 & 0.4486 & Tidak Stasioner & -8.645552 & 0.0000 & Stasioner \\
TBH & -2.379636 & 0.1511 & Tidak Stasioner & -10.26851 & 0.0001 & Stasioner \\
NPF & -1.119149 & 0.7037 & Tidak Stasioner & -3.912111 & 0.0033 & Stasioner \\
ROA & -3.477143 & 0.0115 & Stasioner & -11.76207 & 0.0001 & Stasioner \\
BOPO & -1.694787 & 0.4295 & Tidak Stasioner & -13.67703 & 0.0001 & Stasioner \\
\hline
\end{tabular}


dapat mengetahui variabel manakah yang akan memberi response terbesar terhadap adanya shock.

Variance decomposition (VD) merupakan bagian dari analisis VECM yang menyediakan perkiraan tentang tingkat kontribusi suatu variabel terhadap perubahan variabel itu sendiri dan variabel lainnya pada beberapa periode mendatang. Penelitian ini mengetahui kontribusi pembiayaan, DPK, ROA, CAR, FDR, $\mathrm{TBH}, \mathrm{NPF}$ dan BOPO terhadap pembiayaan. Dengan demikian variabel mana yang diperkirakan akan memiliki kontribusi terbesar terhadap pembiayaan dapat diketahui.

\section{PEMBAHASAN}

\section{Uji Stasioneritas/Unit Root Test}

Berdasarkan hasil uji yang diperoleh menunjukkan variabel yang stasioner di level hanya CAR dan ROA sedangkan enam variabel yang lain menunjukkan tidak stasioner pada level (t-statistic < test critical value), sehingga perlu pengujian stasioneritas pada first difference-nya. Dari tabel 1 di dapat terlihat bahwa Uji ADF pada first difference yang dilakukan menunjukkan semua data telah stasioner (t-statistic > test critical value) pada a $=1 \%$ dengan tingkat keyakinan 99 persen.

\section{Penentuan lag optimum}

Kandidat lag yang akan dicari dengan menggunakan kriteria informasi yang tersedia, yaitu criteria likehood ratio (LR), final prediction error (FPE), akaike. information criterion (AIC), shwarz information criterion (SC), dan hannanquin criterion (HQ). Apabila kriteria informasi merujuk pada sebuah kandidat lag, maka lag tersebut yang akan dipilih untuk melanjutkan estimasi pada tahapan berikutnya. Hasil uji lag optimum pada kriteria informasi SC dan HQ menunjukkan pada angka 1 sedangkan karena alasana degree of fredom untuk kriteria informasi FPE dan AIC pada lag 6 tidak digunakan

\section{Uji Stabilitas VAR}

Uji stabilitas dilakukan untuk menentukan apakah lag dihasilakn merupakan lag maksimum VAR yang stabil. Model VAR yang stabil dapat dilihat dari nilai inverse roots karakteristik AR polinomialnya. Suatu sistem VAR dikatakan stasioner jika seluruh roots-nya memiliki modulus lebih kecil dari satu dan terletak di dalam unit circle. Nilai modulus terlihat pada tabel 3 pada model berkisar antara 0.2939 - 0.9676. Berdasarkan hasil tersebut dapat disimpulkan bahwa model VAR stabil pada panjang sehingga bisa dilakukan uji FEDV pada model ini yang menghasilkan output yang valid.

\section{Tabel 3. Hasil Uji Stabilitas VAR}

\begin{tabular}{lc}
\hline \multicolumn{1}{c}{ Root } & Modulus \\
\hline 0.967601 & 0.967601 \\
$0.916701-0.058361 \mathrm{i}$ & 0.918557 \\
$0.916701+0.058361 \mathrm{i}$ & 0.918557 \\
0.802787 & 0.802787 \\
$0.580254-0.372654 \mathrm{i}$ & 0.689613 \\
$0.580254+0.372654 \mathrm{i}$ & 0.689613 \\
0.684178 & 0.684178 \\
$-0.011298-0.491751 \mathrm{i}$ & 0.491880 \\
$-0.011298+0.491751 \mathrm{i}$ & 0.491880 \\
$-0.138855-0.415340 \mathrm{i}$ & 0.437936 \\
$-0.138855+0.415340 \mathrm{i}$ & 0.437936 \\
-0.410513 & 0.410513 \\
$0.193911-0.307985 \mathrm{i}$ & 0.363945 \\
$0.193911+0.307985 \mathrm{i}$ & 0.363945 \\
$-0.293024-0.022923 \mathrm{i}$ & 0.293919 \\
$-0.293024+0.022923 \mathrm{i}$ & 0.293919 \\
\hline
\end{tabular}

No root lies outside the unit circle.

VAR satisfies the stability condition.

Tabel 2. Pengujian Lag Optimal

\begin{tabular}{ccccccc}
\hline Lag & LogL & LR & FPE & AIC & SC & HQ \\
\hline 0 & -681.3146 & NA & 0.162891 & 20.88832 & 21.15373 & 20.99320 \\
1 & -282.4161 & 689.0064 & $6.46 \mathrm{e}-06$ & 10.73988 & $13.12860^{*}$ & $11.68378^{*}$ \\
2 & -223.2515 & 87.85052 & $8.12 \mathrm{e}-06$ & 10.88641 & 15.39843 & 12.66932 \\
3 & -153.2264 & $87.00093^{*}$ & $8.45 \mathrm{e}-06$ & 10.70383 & 17.33915 & 13.32576 \\
4 & -78.03392 & 75.19245 & $9.64 \mathrm{e}-06$ & 10.36466 & 19.12328 & 13.82561 \\
5 & 3.390649 & 61.68528 & $1.40 \mathrm{e}-05$ & 9.836647 & 20.71857 & 14.13661 \\
6 & 155.3623 & 78.28844 & $5.46 \mathrm{e}-06^{*}$ & $7.170838^{*}$ & 20.17606 & 12.30982 \\
\hline
\end{tabular}


Tabel 4. Uji Kointegrasi

\begin{tabular}{ccccc}
\hline $\begin{array}{c}\text { Hypothesized } \\
\text { No. of } \text { CE }(\text { s })\end{array}$ & Eigenvalue & $\begin{array}{c}\text { Trace } \\
\text { Statistic }\end{array}$ & $\begin{array}{c}\mathbf{0 . 0 5} \\
\text { Critical Value }\end{array}$ & Prob.** \\
\hline None * & 0.510970 & 181.6935 & 159.5297 & 0.0018 \\
At most 1 * & 0.405377 & 132.3356 & 125.6154 & 0.0182 \\
At most 2 * & 0.379206 & 96.46745 & 95.75366 & 0.0446 \\
At most 3 & 0.298661 & 63.57130 & 69.81889 & 0.1424 \\
At most 4 & 0.275007 & 39.09259 & 47.85613 & 0.2566 \\
At most 5 & 0.101451 & 16.90266 & 29.79707 & 0.6472 \\
At most 6 & 0.074830 & 9.521432 & 15.49471 & 0.3193 \\
At most 7 * & 0.058437 & 4.154743 & 3.841466 & 0.0415 \\
\hline
\end{tabular}

\section{Uji Kointegrasi}

Pengujian kointegrasi penting untuk dilakukan untuk melihat hubungan jangka panjang variabel pembiayaan, DPK, ROA, CAR, FDR TBH NPF dan BOPO dalam penelitian ini. Dari hasil uji stasioner diketahui bahwa tidak semua data stasioner pada tingkat level maka dilakukan estimasi dengan menggunakan model VECM. Untuk mengunakan model VECM sebelumnya perlu dilakukan pengujian kointegrasi terlebih dahulu untuk mengetahui hubungan jangka panjang antar variabel. Dengan uji kointegrasi dapat diketahui keseimbangan data dalam jangka penjang mendekati nilai nol.

Hubungan kointegrasi dalam penelitian ini dapat dilihat dari nilai trace statistic lebih besar dari critical value, pada $\mathrm{a}=\%$. Berdasarkan tabel 5 dapat dilihat bahwa pada model terdapat minimal dua rank kointegrasi pada $a=5 \%$ (tingkat keyakinan 95\%), yang berarti terdapat minimal dua persamaan kointegrasi yang mampu menerangkan keseluruhan masing-masing model tersebut. Hal ini berarti terdapat hubungan jangka panjang antara perkembangan pembiayaan dengan faktorfaktor penentunya, dalam hal ini pembiayaan bank syariah yang tercermin dalam DPK, CAR NPF, TBH, FDR, ROA dan BOPO yang hasilnya akan diperjelas pada estimasi VECM

\section{Hasil Estimasi VECM Perkembangan Pembiayaan dan Faktor-Penentunya}

VECM mampu melihat hubungan jangka panjang dan keberadaan dinamisasi jangka pendek variabel-variabel endogen agar konvergen ke dalam hubungan kointegrasinya. Model VECM sebagai model terbaik berdasarkan kriteria goodness of fit yang harus dimiliki model. VECM diharapkan lebih mampu menggambarkan hubungan DPK, ROA, CAR, FDR, TBH NPF dan ROA dengan pembiayaan yang sebenarnya dibandingkan dengan menggunakan model lain.

Tabel 6 merupakan hasil estimsi VECM perkembangan laju pembiayaan bank syariah yang memperlihatkan hubungan antar variabel pada jangka panjang. Dapat terlihat bahwa variabel yang mempengaruhi pembiayaan dalam jangka panjang adalah DPK, CAR, FDR, $\mathrm{TBH}$, NPF dan BOPO pada lag-1. Sementara itu, variabel LNDPK(-1) atau perkembangan DPK lag-1 berpengaruh negatif secara signifikan terhadap laju pembiayaan bank syariah, yakni ketika terjadi peningkatan sebesar satu persen pada pertumbuhan simpanan/ DPK maka akan menurunkan pembiayaan pembiayaan sebesar $-0.479890 \%$. Hasil ini sesuai dengan hasil penelitian Meydianawati (2007), Qolby (2013), Dyatama (2015), Priyanto (2016), Jamilah (2016) dan Destiana (2016)

Tabel 5. Hasil Regresi Jangka Panjang

\begin{tabular}{|c|c|c|c|}
\hline \multirow{2}{*}{ Cointeg Eq: } & \multicolumn{3}{|c|}{ LOG(FIN(-1)) } \\
\hline & & Std Error & $\mathrm{t}$ stat \\
\hline LOG(FIN(-1)) & 1.000 .000 & & \\
\hline LOG(DPK(-1)) & -0.479890 & $(0.18800)$ & {$[-2.55262]^{*}$} \\
\hline $\operatorname{ROA}(-1)$ & 0.057457 & $(0.06092)$ & [ 0.94319] \\
\hline CAR(-1) & 0.085592 & $(0.03175)$ & {$[2.69562]^{*}$} \\
\hline $\operatorname{FDR}(-1)$ & 0.020961 & $(0.00458)$ & [ 4.57985$]^{*}$ \\
\hline $\mathrm{TBH}(-1)$ & 0.012717 & $(0.00268)$ & {$[4.75071]^{*}$} \\
\hline NPF(-1) & 0.064112 & $(0.04132)$ & [ 1.55160$]$ \\
\hline BOPO(-1) & -0.056478 & $(0.00835)$ & {$[-6.76060]^{*}$} \\
\hline C & -5.669 .786 & & \\
\hline
\end{tabular}

Seperti dalam penelitian sebelumnya yang dilakukan Giannini, (2013), Priyanto (2016) dan Jamilah, (2016) bahwa CAR berpengaruh 
terhadap pembiayaan. Dimana koefisien pada CAR sebesar $0.085592 \%$ yang artinya pembiayaan akan naik sebesar $0.085592 \%$ bila ada kenaikan CAR sebesar 1\%. Semakin besar CAR menunjukkan semakin besar kemampuan bank syariah untuk menutup resiko aset atas modal bank yang digunakan sehingga semakin tinggi CAR maka manajemen bank akan merasa lebih nyaman untuk menyalurkan pembiayaan.

Semakin tinggi rasio pendanaan terhadap pembiayaan akan mempengaruhi semakin besarnya penyaluran pembiayaan bank syariah kepada sektor ekonomi. Nilai koefisien $0.020961 \%$ menunjukkan pengaruh pembiayaan apabila FDR naik sebesar 1\%. Hal ini menunjukkan bahwa DPK tidak berpengaruh secara langsung terhadap besarnya pembiayaan bank syariah. Manajemen cenderung lebih memperhitungkan CAR, FDR, TBH dan BOPO dalam menentukan tingkat pembiayaan, selain itu pengaruh kondisi ekonomi makro. Hasil penelitian ini sama dengan penelitian Meydianawathi (2007), Kusumati (2013), Nasution (2016) dan Adzimatinur et al, (2016) yang menunjukkan bahwa DPK berpengaruh negatif terhadap pembiayaan.

$\mathrm{TBH}$ berpengaruh positif terhadap pembiayaan yang artinya kenaikan 1\% TBH akan mempengaruhi kenaikan pembiayaan sebesar $0.012717 \%$. Temuan ini berbeda dengan temuan Giannini (2013), Wahab (2014) dan Adzirmatinur et al (2015) menemukan tidak adanya pengaruh $\mathrm{TBH}$ terhadap pembiayaan. Porsi terbesar pembiayaan bank syariah pada pembiayaan dengan skim jual beli sedangkan skim bagi hasil relatif lebih sedikit dibanding jual beli. Keadaan ini mengakibatkan besarnya pembiayan bank syariah dipengaruhi oleh tingkat margin jual beli daripada besarnya tingkat nisbah bagi hasil. Kenaikan bagi hasil bisa saja mempengaruhi turunnya pembiayaan, namun prosentase terbesar pembiayaan dalam bentuk skim jual beli dimana tingkat margin lebih berpengaruh terhadap besaran pembiayaan secara umum.

Tingkat NPF tidak berpengaruh terhadap tingkat pembiayaan bank syariah. Tingkat NPF pada bank syariah relatif rendah dan bergerak konstan dari tahun ke tahun sehingga pergerakan NPF tidak berpengaruh terhadap turunnya pembiayaan. Penelitian ini sebagai penegas dari hasil penelitian sebelumnya yang dilakukan Giannini (2013), Wahab (2014), Jamilah (2016), Nasution (2016) yang menyatakan bahwa NPF tidak berpengaruh terhadap pembiayaan. Tidak berpengaruhnya NPF terhadap pembiayaan mengandung arti bahwa manajemen bank syariah cenderung kurang mempermasalahkan NPF sebagai indikator menentukan kebijakan pembiayaan. Keadaan ini disebabkan masalah NPF masih dibawah tolerasi untuk diatasi dan obyek pembiayaan bank syariah masih dianggap aman dalam jangka panjang

Sesuai dengan penelitian Jamilah, (2016) menemukan bahwa BOPO berpengaruh negatif terhadap ROA. Kenaikan satu persen BOPO menpengaruhi turunnya pembiayan sebesar $-0.056478 \%$ pada bank syariah. Besarnya pembiayaan akan mempengaruhi besarnya pendapatan bank syariah. Semakin besar pembiayaan diberikan pada mitra maka potensi mendapatkan pendapatan semakain besar atau rasio biaya atas pendapatan akan semakin menurun. Apabila bank menurunkan pembiayaan maka akan menurunkan pendapatan dengan begitu BOPO meningkat. Bagi bank lebih mudah menaikkan pendapatan dari pembiayaan lebih mudah daripada menurun biaya operasional. Manajemen bank syariah menyadari bahwa meningkatkan kinerja keuangan dengan meningkatkan pendapatan dari pembiayan untuk menurunkan BOPO.

\section{Hasil VECM (persamaan jangka pendek/ short term equation)}

Dapat dilihat bahwa pada pada jangka pendek koefisien persamaam kointegrasi 1/

Tabel 6. Persamaan Jangka Pendek

\begin{tabular}{|c|c|c|c|}
\hline \multirow{2}{*}{ Error Correction: } & \multicolumn{3}{|c|}{ D(LOG(FIN)) } \\
\hline & & Std Error & t-test \\
\hline CointEq1 & 0.071295 & $(0.02960)$ & [ 2.40882] \\
\hline $\mathrm{D}(\mathrm{LOG}(\mathrm{FIN}(-1)))$ & 0.524856 & $(0.25991)$ & {$[2.01935]^{*}$} \\
\hline $\mathrm{D}(\mathrm{LOG}(\mathrm{DPK}(-1)))$ & -0.261929 & $(0.31322)$ & {$[-0.83624]$} \\
\hline $\mathrm{D}(\operatorname{ROA}(-1))$ & 0.006336 & $(0.01134)$ & {$[0.55872]$} \\
\hline $\mathrm{D}(\mathrm{CAR}(-1))$ & -0.002883 & $(0.00454)$ & {$[-0.63471]$} \\
\hline $\mathrm{D}(\mathrm{FDR}(-1))$ & $-6.50 \mathrm{E}-05$ & $(0.00177)$ & {$[-0.03677]$} \\
\hline $\mathrm{D}(\mathrm{TBH}(-1))$ & -0.000202 & $(0.00062)$ & {$[-0.32555]$} \\
\hline $\mathrm{D}(\mathrm{NPF}(-1))$ & 0.028999 & $(0.01851)$ & [ 1.56634$]$ \\
\hline $\mathrm{D}(\mathrm{BOPO}(-1))$ & 0.005618 & $(0.00140)$ & {$[4.01209]^{*}$} \\
\hline $\mathrm{C}$ & 0.007961 & $(0.00566)$ & [1.40601] \\
\hline
\end{tabular}


CointEq1 sebesar 0.071295 signifikan, ini adalah koefisien speed of adjusment to equilibrium yang bermakna setiap bulan kesalahan dikoreksi sebesar $7.1295 \%$ menuju target optimal pembiayaan .

Ini bukti adanya mekanisme penyesuaian dari jangka pendek menuju jangka panjang yang ditunjukkan dengan kesalahan kointegrasi yang signifikan dan bernilai 0.071295 (CointEq1:
0.071295). Variabel lain yang mempengaruhi laju pembiayaan dalam jangka pendek adalah pembiayaan lag 1; NPF lag-1; dan BOPO lag1; sementara DPK, ROA, CAR, FDR, TBH dan NPF tidak berpengaruh secara signifikan. Untuk lebih memperjelas hasil jangka panjang dan jangka pendek VECM ini, dapat disimak pada analisis IRF dan FEVD.

Response to Cholesky One S.D. Innovations

Response of LOG(FIN) to LOG(FIN)

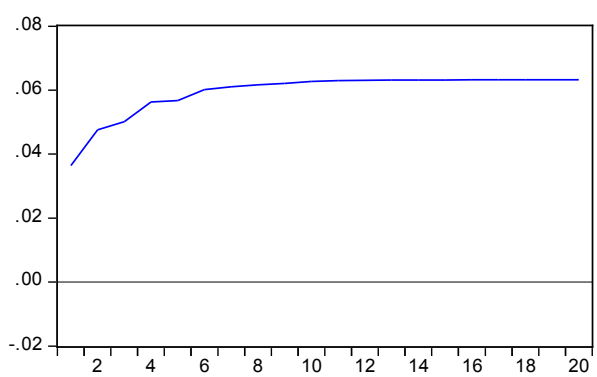

Response of LOG(FIN) to ROA

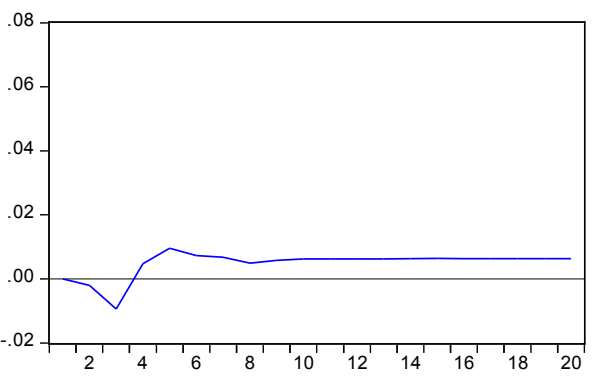

Response of LOG(FIN) to FDR

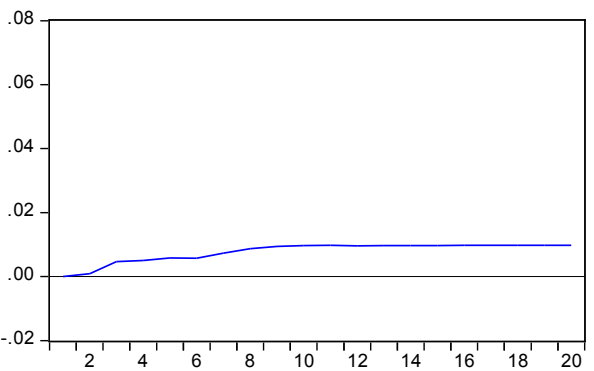

Response of LOG(FIN) to NPF

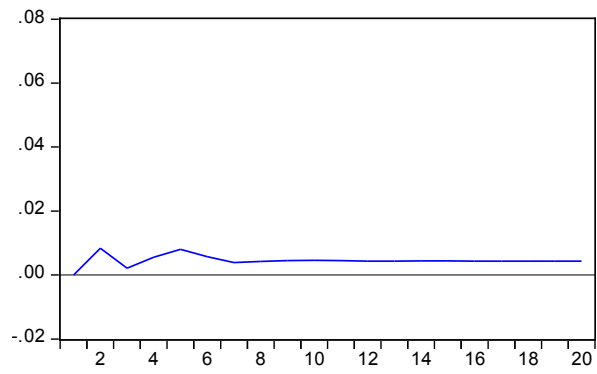

Response of LOG(FIN) to LOG(DPK)

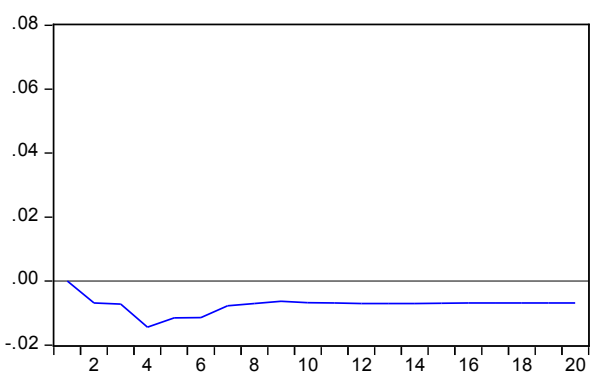

Response of $\operatorname{LOG}(\mathrm{FIN})$ to $\mathrm{CAR}$

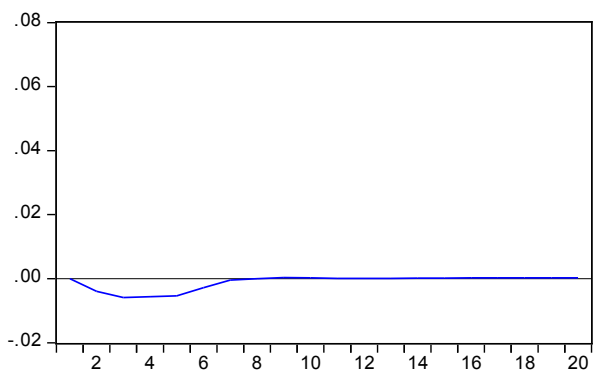

Response of LOG(FIN) to TBH

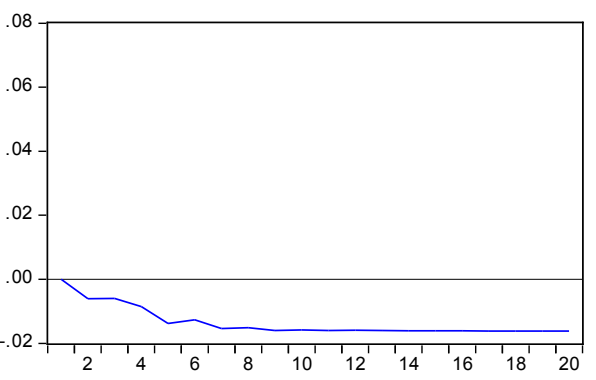

Response of LOG(FIN) to BOPO

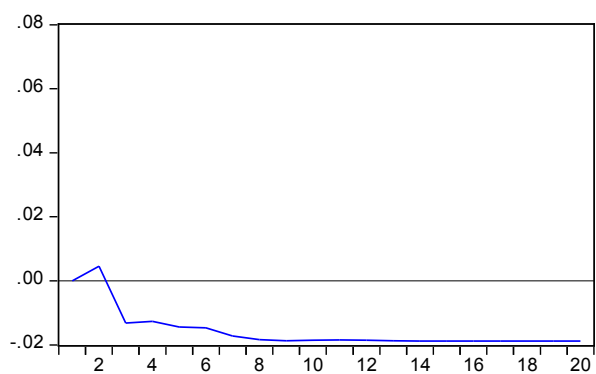

Gambar 2. Hasil Impulse Response Function 


\section{IRF ( Impulse Response Function)}

Dalam gambar IRF, nilai standar deviasi ditunjukkan oleh sumbu vertikal yang mengukur seberapa besar respon yang akan diberikan oleh variabel pembiayaan, DPK, ROA, CAR, FDR $\mathrm{TBH}, \mathrm{NPF}$ dan $\mathrm{BOPO}$ apabila terjadi goncangan terhadap variabel pembiayaan. Sedangkan, sumbu horizontal menunjukkan lamanya waktu (bulan) dari respon yang diberikan terhadap goncangan. Bila respon pembiayaan di atas sumbu horizontal menunjukkan bahwa goncangan akan memberikan pengaruh yang positif. Sebaliknya apabila respon pembiayaan dibawah sumbu horizontal menunjukkan bahwa goncangan berpengaruh negatif. Gambar 2 menunjukkan grafik IRF dari masing-masing variabel sebagai respon.

Analisis IRF dengan pembiayaan sebagai respon menyimpulkan bahwa di dalam 20 tahun mendatang, respon tertinggi adalah respon pembiayaan terhadap pembiayaan itu sendiri, yang diperkirakan akan stabil pada standar deviasi sepuluh. IRF tersebut menunjukkan bahwa pada saat ada goncangan pada pembiayaan, maka pembiayaan itu sendiri akan merespon positif sebesar 3.64\% pada bulan pertama dan kemudian mengalami kenaikan secara bertahap pada bulan berikut. Mencapai tingkat kestabilan mulai pada bulan ke-10 dan seterusnya pada tingkat $\pm 6,32 \%$

Respon negatif pembiayaan terhadap goncangan yang terjadi pada DPK ditunjukkan pada bulan kedua sebesar $0,68 \%$. Responnegatif berlanjut pada bulan ke-3 dan titik puncaknya pada bulan ke-4 sebesar $-1,44 \%$. Kemudian terdapat kenaikan respon pembiayaan terhadap DPK pada bulan ke-6 sampai ke-7, kestabilan terjadi pada bulan ke-8 dengan dengan tingkat respon sebesar $-0,70 \%$. Respon negatif pembiayaan bukan hanya DPK tetapi juga pada ROA. Pembiayaan memberikan respon negatif terhadap goncangan pada ROA di bulan kedua sebesar $-0,20 \%$. Puncak penurunan pada bulan ke-4 dengan tingkat respon sebesar $-0,94 \%$ dan kemudian meningkat positif pada bulan kelima dengan tingkat 0,95\%. Keadaan stabil ketika pada bulan ke-10 dengan respon pembiayaan terhadap ROA sebesar 0,62\%

Respon negatif pembiayaan terhadap CAR terjadi pada bulan kedua sebesar - 0,39\% sampai akhirnya puncak penurunan pada bulan ke-3 dengan respon sebesar -0,59. Pada bulan ke-4 menunjukkan mengalami penurunan sampai akhirnya pada bulan ke-16 sebesar 0,02\% menunjukkan kestabilan meski masih terdapat fluktuasi yang relatif kecil. Berbeda dengan respon terhadap CAR, pembiayaan merespon positif terhadap goncangan FDR. Respon pembiayaan terhadap goncangan yang terjadi pada FDR terjadi bulan ke-2 dengan tingkat 0,09\% kemudian goncangan meningkat pada bulan berikutnya. Namun demikian, respon positif pembiayaan terhadap FDR cenderung mengalami kenaikan dengan trend stabil hingga bulan ke-9 dan respon pembiayaan mulai stabil pada tingkat $0,96 \%$ di bulan ke-10

TBH juga memberikan pengaruh pada saat terjadnya goncangan, namun respon positif dari pembiayaan baru ditunjukkan pada bulan kedua. Gonjangan terjadi pada bulan kedua dengan tingkat $-0,60 \%$, penurunan ini terus berlanjut sampai pada bulan ke-6. Kestabilan terjadi pada bulan ke-7 dengan tingkat respon pembiayaan terhadap TBH sebesar 1,54\%. Di lain pihak, pada bulan kedua pembiayaan memberikan respon positif terhadap goncangan yang terjadi pada NPF sebesar $0,83 \%$. Respon pembiayaan terhadap NPF mengalami fluktuasi pada bulan ke-3 sampai bulan ke-4 dan keadaan stabil pada bulan ke 9 dengan tingkat respon sebesar $0,45 \%$

Pembiayaan belum memberikan respon terhadap goncangan pada BOPO di bulan pertama. Respon positif mulai ditunjukan oleh pembiayaan pada bulan kedua. Terjadi peningkatan pada bulan ke-2 dengan tingkat $0,45 \%$. Namun pada bulan ke-23 respon pembiayaan terhadap BOPO menjadi negatif dengan tingkat respon sebesar $-0,13 \%$. Respon negatif pembiayaan pada $\mathrm{BOPO}$ pada kondisi stabil pada tingkat $0,18 \%$ pada bulan ke- 8 sampai akhir periode pengamatan. Trend respon pembiayaan terhadap BOPO hampir sama dengan TB. Respon pembiayaan terhadap BOPO lebih fluktuatif pada awal periode tetapi lebih cepat stabil respon pembiayaan terhadap BOPO daripada $\mathrm{TBH}$

\section{Forecast Error Variance Decomposition (FEVD)}

Variance decomposition (VD) untuk mengetahui kontribusi suatu variabel 
Tabel 7. Variance Decomposition of LOG(FIN)

\begin{tabular}{cccccccccc}
\hline Period & S.E. & LOG(FIN) & LOG(DPK) & ROA & CAR & FDR & TBH & NPF & BOPO \\
\hline 1 & 0.036451 & 100.0000 & 0.000000 & 0.000000 & 0.000000 & 0.000000 & 0.000000 & 0.000000 & 0.000000 \\
2 & 0.061555 & 94.86158 & 1.232 .484 & 0.107305 & 0.416837 & 0.022926 & 0.972360 & 1.845 .615 & 0.540898 \\
3 & 0.081940 & 90.97047 & 1.467 .167 & 1.388 .638 & 0.755664 & 0.338166 & 1.075 .218 & 1.105 .758 & 2.898 .924 \\
4 & 0.102139 & 88.91608 & 2.934 .580 & 1.109 .402 & 0.786492 & 0.461088 & 1.394 .753 & 1.004 .222 & 3.393 .382 \\
5 & 0.120003 & 86.75985 & 3.039 .752 & 1.441 .291 & 0.769986 & 0.571008 & 2.340 .110 & 1.175 .881 & 3.902 .120 \\
6 & 0.136572 & 86.37990 & 3.043 .884 & 1.400 .048 & 0.636360 & 0.615485 & 2.667 .401 & 1.083 .128 & 4.173 .792 \\
7 & 0.151939 & 85.93220 & 2.720 .380 & 1.327 .576 & 0.514875 & 0.726953 & 3.183 .875 & 0.939799 & 4.654 .342 \\
8 & 0.166216 & 85.58091 & 2.453 .995 & 1.196 .677 & 0.430224 & 0.881935 & 3.490 .205 & 0.849258 & 5.116 .801 \\
9 & 0.179649 & 85.20546 & 2.225 .277 & 1.129 .296 & 0.368681 & 1.031 .071 & 3.779 .636 & 0.790021 & 5.470 .553 \\
10 & 0.192357 & 84.94823 & 2.065 .097 & 1.091 .132 & 0.321791 & 1.152 .944 & 3.970 .661 & 0.745738 & 5.704 .403 \\
\hline
\end{tabular}

pembiayaan, DPK, ROA, CAR, FDR, TBH, NPF dan BOPO terhadap perubahan variabel pembiayaan pada beberapa periode mendatang. Tabel 8, analisis VD menunjukkan bahwa variabel yang diperkirakan akan memiliki kontribusi paling besar terhadap pembiayaan pada masa sepuluh tahun kedepan adalah pembiayan sendiri dengan rata-rata kontribusi per tahun sebesar $88,95 \%$, yang diikuti oleh kontribusi BOPO sebesar 3,53\%, TBH sebesar 2,19\% , DPK sebesar 2.11\% ROA sebesar 1.00\%, NPF sebesar $0,62 \%$, FDR sebesar 0,21 dan CAR $0,31 \%$ yang mendekati nol persen.

Dari hasil rata-rata persentase pada masing-masing variabel tersebut dapat diketahui bahwa BOPO memiliki kontribusi terbesar disusul TBH, DPK, ROA dan NPF dalam mempengaruhi besarnya pembiayaan pada bank syariah. Sementara itu, tingkat NPF dan CAR menunjukkan kontribusi terhadap pembiayaan yang paling rendah dibanding variabel lain. Oleh karena, NPF dan CAR bagi manajemen bank syariah untuk penentukan besaran pembiayaan dibanding variabel yang lain.

Dilihat dari trend setiap periode pada VD menunjukkan bahwa kontribus pembiayaan terhadap pembiayaan cenderung mengalami penurunan setia bulan hingga akhir pengamatan. Keadaan berbeda pada DPK yang menunjukkan trend yang cenderung meningkat pada bulan pertama sampai ke-6 namun pada bulan ke-7 kontribusi DPK terhadap pembiayaan mengalami penurun. Setelah DPK, variabel yang cukup besarnya terhadap pembiayaan adalah BOPO. Kontribusi BOPO menunjukkan kenaikan dari bulan ke bulan bahkan kontribusi pada bulan ke-6 lebih besar daripada kontribusi DPK terhadap pembiayaan.
Demikianjuga dengan TBHmenunjukkan kontribusi pada pembiayaan yang terus meningkat dari bulan pertama sampai bulan ke-10. ROA menunjukkan kontribusi kepada pembiayaan dengan nilai yang fluktuatif dari bulan pertama sampai ke-10. Kontribusi NPF terhadap pembiayaan mengalami penurunan dari bulan pertama sampai ke-10. Kontribusi FDR terhadap pembiayaan mengalami kenaikan dari periode-periode. Sedangkan kontribusi NPF terhadap pembiayaan menunjukkan nilai yang menurun dari bulan ke bulan. Kontribusi CAR terhadap pembiayaan termasuk yang paling rendah dan cenderung kontribusi setiap periode menunjukkan nilai yang semakin menurun.

\section{KESIMPULAN}

Hasil penelitian menunjukkan bahwa dalam jangka panjang variabel DPK, CAR, FDR, dan TBH berpengaruh positif terhadap pembiayaan, sedangkan BOPO berpengaruh negatif terhadap pembiayaan. Berbeda dengan variabel yang lain dalam jangka panjang ROA tidak berpengaruh terhadap pembiayaan. Temuan ini menunjukkan bahwa manajemen bank syariah dalam menentukan volume dan alokasi pembiayaan pada produk bagi hasil, jual beli dan sewa dipengaruhi oleh variabel DPK, CAR, FDR, TBH dan BOPO. Diantara lima variabel tersebut yang paling berpengaruh adalah BOPO disusul dengan TBH kemudian FDR dan NPF bukan menjadi pertimbangan utama manajemen untuk menentukan pembiayaan. Kenyataan ini menunjukkan bahwa manajemen sangat memperhitungkan tingkat kemampuan bank dalam menutup 
beban operasional (BOPO). Selain BOPO, manajemen bank memperhatikan selanjutnya adalah nisbah tingkat bagi hasil (TBH) untuk meningkatkan besaran pembiayaan kepada mitra.

Dalam jangka pendek, variabel yang berpengaruh terhadap pembiayaan adalah pembiayaan sebelumnya dan BOPO. Variabel DPK, CAR, FDR, TBH dan NPF tidak berpengaruh dalam jangka pendek. Kenyataan ini menunjukkan bahwa dalam jangka pendek manajemen bank syariah memperhatikan besaran pembiayan di dasarkan pada kebijakan pembiayaan sebelumnya. Oleh karenanya kebijakan bila trend pembiayan positif maka kebijakan pembiayaan bank syariah secara umum tidak banyak mengalami perubahan dari satu periode dengan periode yang lain. Sementara itu, pengaruh BOPO terhadap pembiayaan bisa diartikan bahwa BOPO menjadikan dasar bagi manajemen bank syariah selama periode penelitian dalam penentuan kebijakan pembiayaan.

Hasil impulse response menunjukkan guncangan yang terjadi pada pembiayaan, ROA, CAR, FDR ROA dan NPF direspon positif oleh pembiayaan dan akan stabil dalam jangka panjang. Guncangan yang terjadi pada variabel lainnya seperti tingkat bagi hasil, DPK, TBH dan BOPO direspon negatif oleh pembiayaan dan akan stabil dalam jangka panjang. Sedangkan hasil dari variance decomposistion menunjukkan bahwa BOPO memiliki kontribusi lebih besar dari variabel DPK, CAR, FDR, TBH dan NPF lain dalam mempengaruhi besarnya pembiayaan. CAR memiliki kontribusi terendah dalam mempengaruhi besaran pembiayaan dibanding variabel lain. Seperti diketahui variasi data CAR relatif konstan dibanding variabel yang lain karena bank syariah berusaha memenuhi CAR yang telah ditentukan BI daripada meningkatkan CAR yang berakibat turunya kemampuan bank dalam memanfaatkan dana untuk pembiayaan.

Dari hasil penelitian ini dapat direkomendasikan untuk penelitian yang akan datang untuk memasukkan variabelvariabel makro ekonomi sebagai penentu pembiayaan. Disamping itu, perlu diteliti tentang potensi dimasing-masing pembiayaan, seperti pembiayaan dengan skim bagi hasil, skim jual beli dan skim sewa jual bank syariah. Dan, penelitian sektor sektor-sektor ekonomi yang potensial sebagai obyek pembiayaan diperlukan untuk membuat kebijakan pembiayaan bank syariah lebih baik.

\section{DAFTAR PUSTAKA}

Adzimatinur, F., S. Hartoyo S, dan R. Wiliasih. 2015. Faktor-faktor yang Mempengaruhi Besaran Pembiayaan Perbankan Syariah di Indonesia.Jurnal Al Muzara'ah, 3 (2): 106-122

Destiana, R. 2016. Analisis Faktor-faktor Internal yang Mempengaruhi Pembiayaan usaha Mikro Kecil dan Menengah (UMKLM) pada Bank Syariah di Indonesia, JRKA. 2 (1): 15-28

Dyatama, N. A dan I, Yuliadi. 2015. Determinan Jumlah Pembiayaan Bank Syariah di Indonesia, Jurnal Ekonomi dan Studi Pembangunan. 16 (1): 73-83

Giannini, G. N.2013.Faktoryang Mempengaruhi Pembiayaan Mudharabah pada Bank Umum Syariah di Indonesia. Accounting Analysis Journal. 2 (1): 96-103

Jamilah. 2016. Faktor-faktor yang Mempengaruhi Pembiayaan Mudharabah pada Bank Umum Syariah di Indonesia. Jurnal Ilmu dan Riset Akuntansi. 5 (4): 1-20

Kusumawati, N.N. 2013. Analisis Pembiayaan Sektor Konstruksi pada Perbankan Syariah di Indonesia. Al-Muzaraah. 1 (2): 191-203.

Meydianawati, L. G. 2007. Analisis Perilaku Penawaran Kredit Perbankan Kepada Sektor UMKM di Indonesia. Buletin Studi Ekonomi. 12 (2). 134-147.

Nasution, Z dan Ulum A. Sl, 2016, Analisis Risiko Pembiayaan Syariah pada Sektor Ekonomi, Jurnal Kompilasi Ilmu Ekonomi, 7 (2): $110-122$

Qolby, L. M. 2013. Faktor-faktor yang Mempengaruhi Pembiayaan pada Perbankan Syariah di Indonesia periode Tahun 2007-2013, Economics Development Analysis Journal. 2 (4): 367-383

Wahab. 2014. Analisa Pengaruh FDR, NPF, Tingkat Bagi Hasil, Kualitas Jasa dan Atribut produk Islam terhadap Tingkat pembiayaan Mudharabah pada Bank Umum Syariah di Semarang, Economica, 5 (2): 104-136 